\title{
EDITORIAL AND COMMENTARIES
}

\section{Structure for Community Participation}

David Sharp

Several public services-education and the environment, for instance-benefit from direct community participation, "direct" here implying something beyond the usual political controls. The benefit is there even if politicians and those running the services would much prefer that the public stayed out of them. It might be thought that with community involvement in health, the less formality the better. This may be true for special cases of peer group activity, such as involvement of the gay community in acquired immunodeficiency syndrome/human immunodeficiency virus (AIDS/HIV) prevention or the use of recent school-leavers rather than teachers to provide sex education. However, community participation across the whole spectrum of health care cannot be sustained without structure.

Even in this so often self-centered age, a sense of community happily does persist, surfacing at times of tragedy, as happened in the aftermath of the September 11, 2001, attacks in the United States and on a smaller scale in the English town of Soham when two schoolgirls were murdered last year. But, what sort of conditions need to be met for there to be a sustained commitment day after day by a community to its collective health, its environment, education, or transport system?

First, there has to be a definition of community, but in cities, the boundaries are blurred. In London, you can only tell which borough you are in by looking at the small print above the names of roads and streets. The boroughs provide many essential services, but their populations are not true communities. Local government reorganization from 1974 resulted in the forced marriages of smaller towns to form bigger, hopefully more efficient, administrative groupings; a generation later, they often still lack a sense of community.

Second, we must have institutions that the communities can look to as theirs, institutions with quality of which they can be proud. It is impossible to describe for those not from the United Kingdom all the changes in hospital organization over the past 30 years. In many places, however, the 1960s objective of district general hospitals with catchment populations of 250,000 or so (i.e., hospitals on a scale to which people could relate) has been diluted. "Big is beautiful" is now the watchword, but communities think differently. There is no more certain way of achieving an embarrassing upsurge in community loyalty than for officials to threaten closure of a beloved, but allegedly inefficient, local "cottage hospital."

The third condition is structure. A common governmental response to pressure for more public involvement is the appointment of lay members to statutory and advisory bodies. The National Health Service (NHS) reorganization of 1974 went 
further and introduced Community Health Councils (CHCs) with lay members from the community, their own budgets, and offices in main-street premises. The CHCs are about to be abolished, together with their parent body, the Association of Community Health Councils of England and Wales (ACHCEW). In their place will be Patients' Forums and a Commission for Patient and Public Involvement in Health, which was due to start work in January 2003. (Further information can be obtained at www.achcew.org.uk.) The condemned ACHCEW now broadly accepts the new arrangements, but only after significant changes of heart by the government. For example, the forums will have budgets from the new commission rather than from the NHS Trusts, for which they will be the watchdogs, as originally proposed; they also will be able to report to the media. The new bodies will have a wider remit than the CHCs, but a central function remains one of promoting the involvement of members of the public in decisions on matters affecting their health.

Budgets for the Patients' Forums had not been set at the time of this writing, and the ACHCEW estimated in October 2002 that the 600 new bodies (replacing the present $184 \mathrm{CHCs}$ ) will require 1,650 staff compared to the present 700 . If they are not starved of money and can remain independent, the Patients' Forums may well provide an appropriate structure for public participation, but I am still anxious that the blurred and confusing boundaries of today's NHS will make forum targets difficult to achieve. 